\title{
Пріоритетність у виборі методу хірургічної корекції кукси після ампутації дистального відді.лу стопи у хворих із різними формами синдрому діабетичної стопи
}

\begin{abstract}
Мета роботи: покращити результати хірургічного лікування хворих із різними формами синдрому діабетичної стопи шляхом вибору адекватного закриття дефекту кукси після трансметатарзальної ампутації.

Матеріали і методи. Проведено аналіз результатів лікування 72 хворих із ускладненим цукровим діабетом 2 типу. Невропатична форма переважала та складала 65,3 \%, невроішемічна - 29,2 \% та ішемічна - 5,5 \% серед усіх оперованих пацієнтів. У всіх хворих встановлено ураження дистального відділу стопи 3 та 4 стадій за класифікацією Meggit-Wagner. Усім пацієнтам виконано трансметатарзальну ампутацію. Для запобігання ускладненням в післяопераційному періоді ампутацію дистального відділу стопи здійснювали електромеханічно-вібраційною методикою із наступним закриттям кукси при невропатичній формі за допомогою вільного нижнього клаптя та при невроішемічній чи ішемічній формах синдрому діабетичної стоп із застосуванням ранньої ксено- чи автодермопластики після гельйотинного методу ампутації.

Результати досліджень та їх обговорення. Даний підхід дав нам можливість закрити дефект дистального відділу кукси у тих групах пацієнтів із невроішемічною та ішемічною формами синдрому діабетичної стопи, де судинні реконструктивні операції неможливо було виконати за клініко-діагностичними ознаками.
\end{abstract}

Ключові слова: синдром діабетичної стопи; трансметатарзальна ампутація; електромеханічний дебридмент; ксенопластика; автодермопластика.

Постановка проблеми і аналіз останніх досліджень та публікацій. Захворювання на цукровий діабет останніми роками набуває ознак пандемії, а розвиток у таких хворих синдрому діабетичної стопи (СДС) сягає до $30 \%[1,9]$. У структурі СДС більшість займають невропатична форма (60-70 \%), невроішемічна (18-25 \%) та ішемічно-гангренозна (5-10\%), кожна з яких спричиняє різноманітні патогенетично зумовлені гнійно-некротичні ускладнення [7, 11, 12]. Основним питанням сьогодення в хірургічному лікуванні різних форм трофічних порушень м'яких тканин нижніх кінцівок у хворих на ЦД, ускладнений СДС, є збереження кінцівки, її опорної та, відповідно, подальшої рухової функції за рахунок пріоритетного виконання малих ампутацій та хірургічної обробки. Тому удосконалення способів діагностики та лікування цієї патології і надалі залишається основною для всіх хірургів, що займаються даною проблемою [2-6, 10].

Мета роботи: покращити результати хірургічного лікування хворих із різними формами синдрому діабетичної стопи шляхом вибору адекватного закриття дефекту кукси після трансметатарзальної ампутації.

Матеріали і методи. В клініці хірургії № 1 імені проф. Л. Я. Ковальчука на базі Тернопільської університетської лікарні в період 2018-
2021 рр. проведено лікування 72 пацієнтів із 2 типом цукрового діабету та різними формами СДС 3 ураженням дистальної частини стопи, що потребувало виконання трансметатарзальної ампутації. Розподіл хворих за формами здійснювали після проведення загальноклінічних досліджень, пальпації основних артерій нижньої кінцівки, визначення больової, температурної, вібраційної чутливості, УЗД доплерографічного обстеження судин, визначення кісточково-плечового індексу, неінвазивної оцінки кисневого статусу артеріальної крові на нижніх кінцівках за допомогою пульсоксиметрії, рентгенобстеження кісток стопи, проведення транскутанної оксиметрії. Таким чином, невропатичну форму СДС діагностовано у 47 (65,3 \%), невроішемічну - 21 (29,2 \%) та ішемічну - у 4 (5,5 \%) обстежуваних пацієнтів. Чоловіків було 39 (54,2 \%), жінок - 33 (45,8 \%). У 19 (26,4 \%) пацієнтів раніше були вже виконані ампутації одного або кількох пальців на рівні основної фаланги або з резекцією головки плюсневої кістки. В 11 (15,3 \%) випадках діагностовано ураження на обох стопах. Керуючись класифікацією Meggit-Wagner 3 стадія 3 глибоким ураженням м'яких тканин із втягненням кісток та плесно-фалангових суглобів із розвитком гнійної остеоартропатії, флегмони чи абсцесів виявлено у 42 пацієнтів - (22 (30,5 \%) з ЗА гострим процесом та 20 (27,8 \%) 3В хронічною глибокою інфекцією); 
4 стадія - гангрена дистальної частини стопи - у 30 хворих (13 (18,1\%) - 4А - суха гангрена та 17 (23,6 \%) - 4В - волога гангрена).

Всім пацієнтам виконано трансметатарзальну ампутацію за допомогою електромеханічного вібраційного методу відрізним диском із швидкоріжучої сталі віброелектроінструментом німецької фірми “Proxxon". Дана методика не чинить пошкоджувальної дії на м'які тканини і швидко в межах 1-2 хвилин здійснює відсічення кісток на будь-якому рівні ступні в точці прикладання та під кутом, вибраним хірургом. Обробку кукси кісток після відсічення здійснювали за методикою, запатентованою нами [8], корундовою головкою за допомогою обертового механізму при швидкості 10000 оборотів фрезера (мікромота) Marathon 3 Champion українсько-корейської фірми SaeYang Ukraine, що використовується в медичній подології.

У протокол післяопераційного лікування були включені препарати інсуліну короткої та продовженої дій, таблетовані цукрознижуючі середники, препарати тіоктової кислоти, комбіновані вітаміни групи В, антиагреганти, низькомолекулярні гепарини, алпростани, антибіотикотерапія згідно з результатами бакпосіву, що призначалися патогенетично вибірково для кожної форми СДС, проводили корекцію анемії як препаратами заліза, так і переливання одногрупної однорезусної крові залежно від клінічної ситуації кожного хворого зокрема.

Результати досліджень та їх обговорення. Всім пацієнтам із невропатичною формою синдрому діабетичної стопи залежно від ширини ураження виконано трансметатарзальну ампутацію за Шарпом: низьку з резекцією головок плюсневих кісток або високу в ділянці середньої третини плюсневих кісток чи вище (рис. 1, 2).

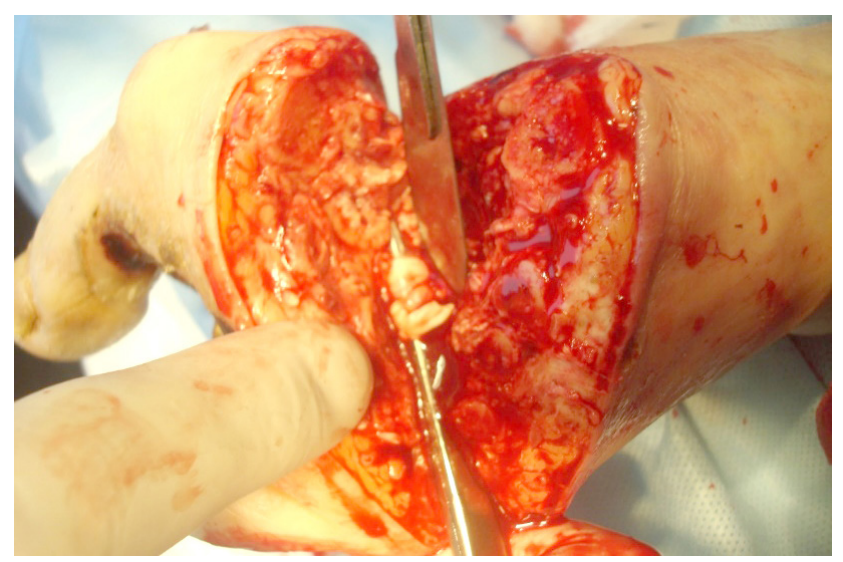

Рис. 1. Видалення сухожильно-фасціальних утворень по тильній та підошовній поверхнях стопи.

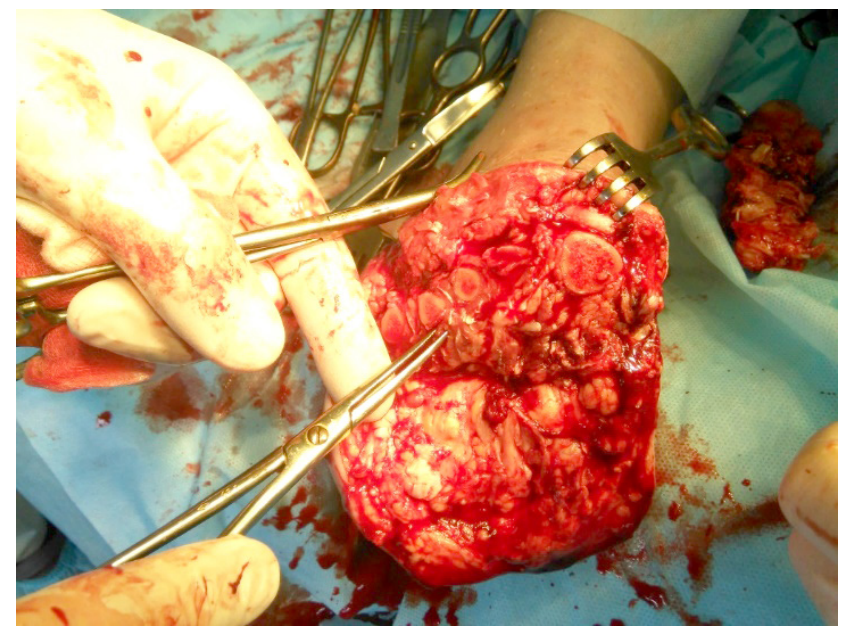

Рис. 2. Формування нижнього клаптя.

Враховуючи збереження кровопостачання, 31 пацієнту з 47 з нейропатичною формою після виконання електромеханічно-вібраційного відсічення та обробки кісток, а також адекватного видалення всіх сухожильно-фасціальних утворень як по тильній, так і підошовній поверхнях дефект вдалося закрити за допомогою нижнього клаптя шляхом підшивання до верхнього окремими вузловими швами ниткою пролен № 2 з обов’язковим введенням мікроірригатора для активно-пасивного дренування рани (рис. 3-5).

16 пацієнтам закриття культі виконували за допомогою ксенопластики та автодермопластики в ранньому періоді після ампутації в зв’язку з тим,

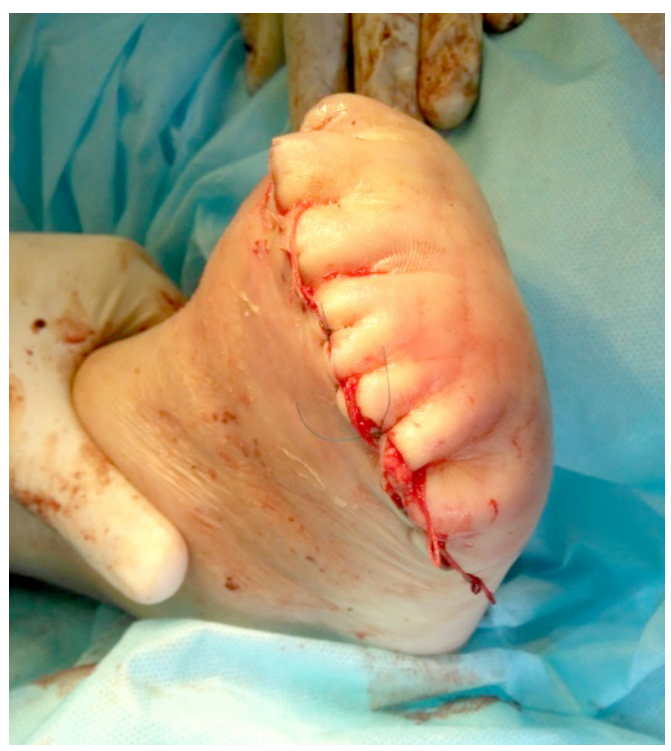

Рис. 3. Формування кукси з закриттям нижнім клаптем при нейропатичній формі СДС із збереженим кровообігом по судинах нижньої кінцівки. 




Рис. 4. Вигляд кукси на 16 добу (виписаний на амбулаторне лікування).

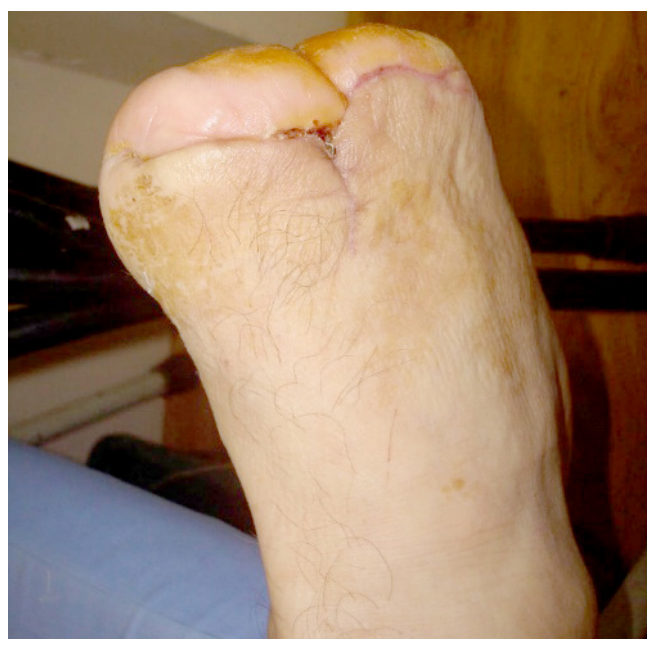

Рис. 5. Вигляд кукси через 1,5 місяця (пацієнт самостійно прийшов на огляд, наявне відновлення оволосіння на культі).

що шкіра та м'які тканини були висіченні внаслідок їх некрозу (рис. 6, 7).

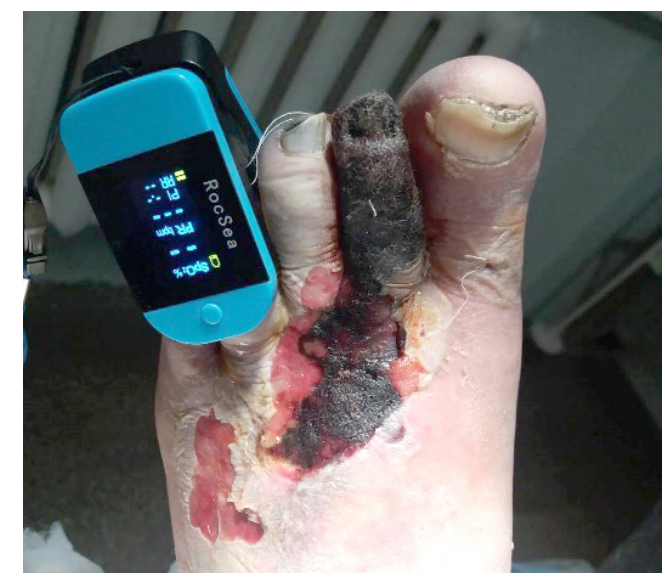

Рис. 6. Вигляд вологої гангрени у пацієнта 3 нейропатичною формою СДС, при пульсоксиметрії показники на периферії не визначаються.

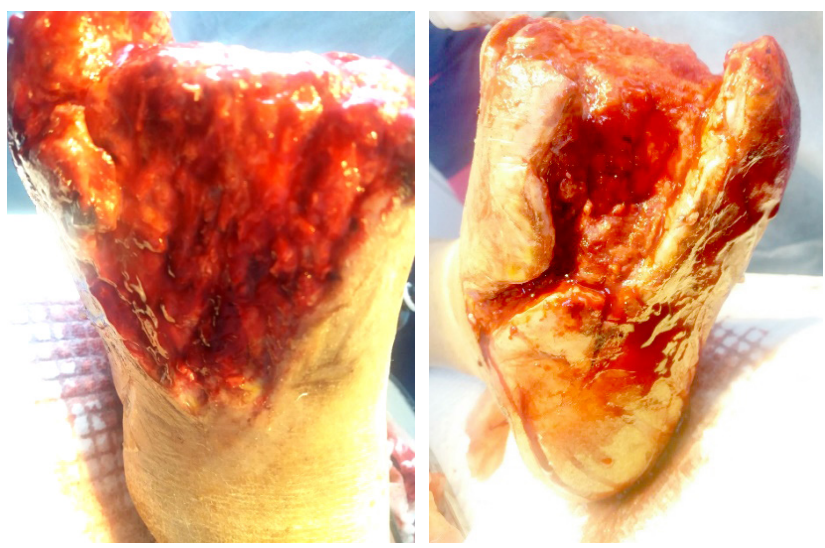

Рис. 7. Ампутація дистального відділу стопи з резекцією головок плесневих кісток із адекватним виділенням усіх сухожильно-фасціальних утворень по тильній та підошовній поверхнях стопи та некректомією в межах здорових тканин.

У такій ситуації вже на 3 добу перебування в стаціонарі для запобігання пересиханню рани, можливому поширенню процесу та для пришвидшення росту грануляційної тканини таким хворим проводили ранню ксенопластику, що сприяло ранньому зникненню больового синдрому, зменшенню набряку кінцівки вже на наступну добу (рис. 8-10).

Швидкий ріст грануляцій дав нам можливість на 9 добу після виконання електромеханічного дебридменту ксеношкіри та електромеханічної корекції виступаючих кісткових елементів, які виникли внаслідок спадання набряку та констрикції



Рис. 8. Рання ксенопластика на 3 добу. 


\section{З ДОСВІДУ РОБОТИ}

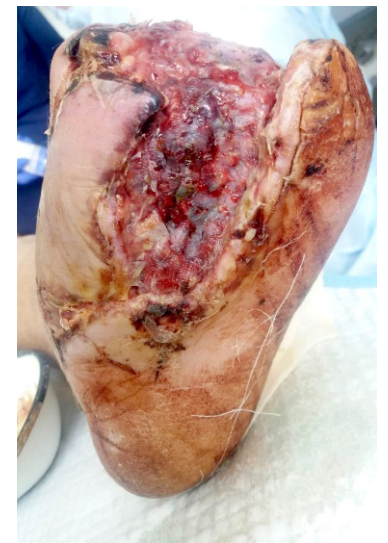

Рис. 9. Поява грануляцій на 9 добу під ксеношкірою.

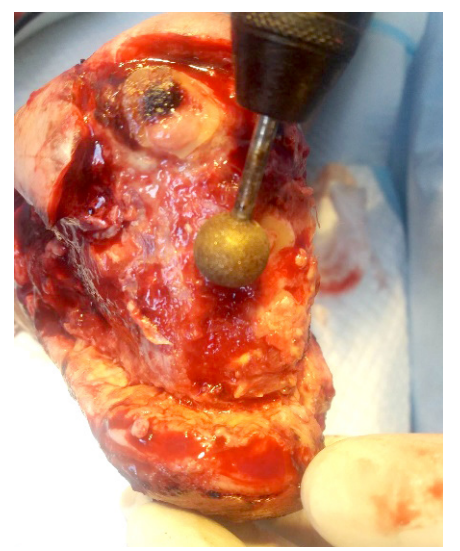

Рис. 10. Електромеханічний дебридмент п/о рани на 10 добу як етап підготовки до наступної автодермопластики.

При невроішемічній та ішемічній формах усім 25 пацієнтам відсікання та обробку кісток та сухожильно-фасціальних утворень були проведені в межах здорових тканин ідентично першому варіанту, однак враховуючи низьке кровопостачання, неможливість виконати реконструктивні операції на судинах гомілковостопної зони та досвід попереднього лікування такої категорії пацієнтів, де після збереження клаптів майже у всіх потребувало проведення їх відсікання в зв'язку з некрозом, ампутацію проведено гельйотинним методом із подальшою електромеханічною обробкою кісток на 2 мм вглиб краю м'яких тканин (рис. 13, 14).

Потім за допомогою корундової головки на швидкості 12000 оборотів проводили електромеханічний дебридмент м'яких тканин та крові на їхній поверхні тривалістю до 1 хвилини та вико-

рани, провести повне закриття рани власними тканинами (рис. 11, 12).
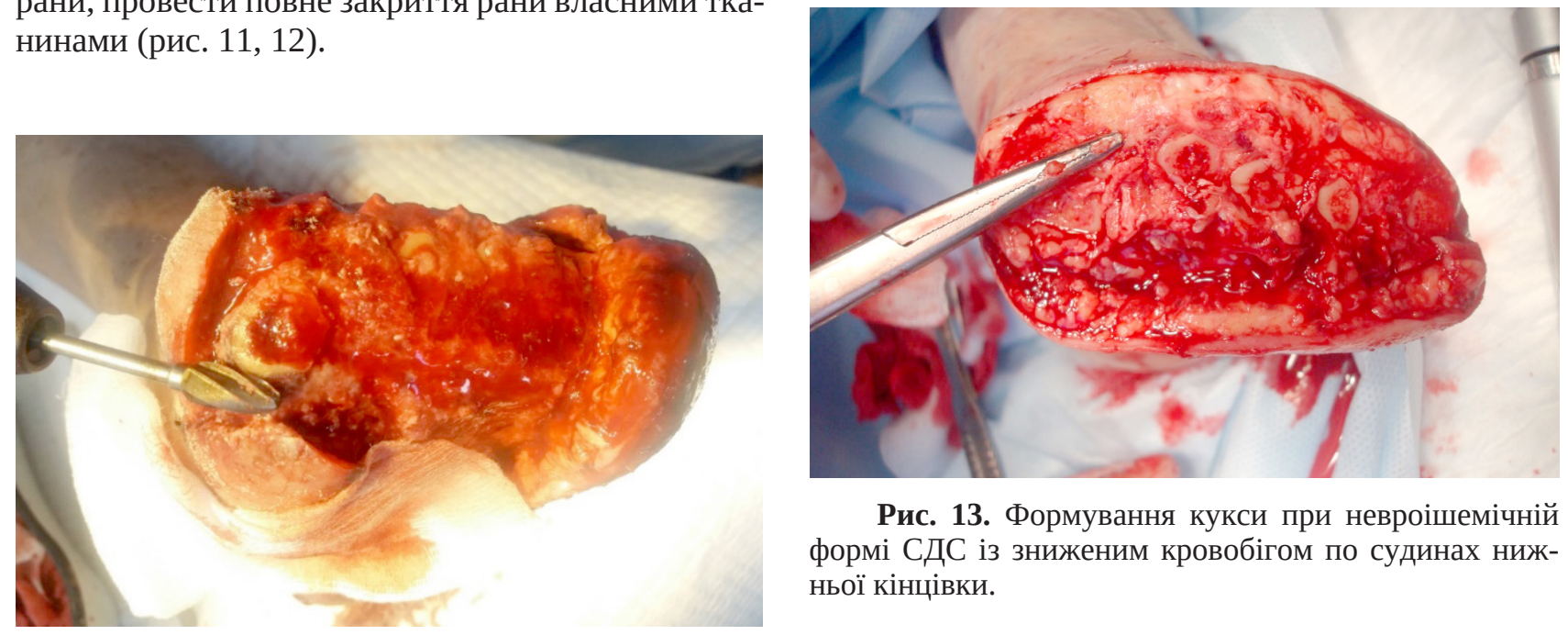

Рис. 13. Формування кукси при невроішемічній формі СДС із зниженим кровобігом по судинах нижньої кінцівки.

Рис. 11. Електромеханічна корекція виступаючих ділянок кісток.
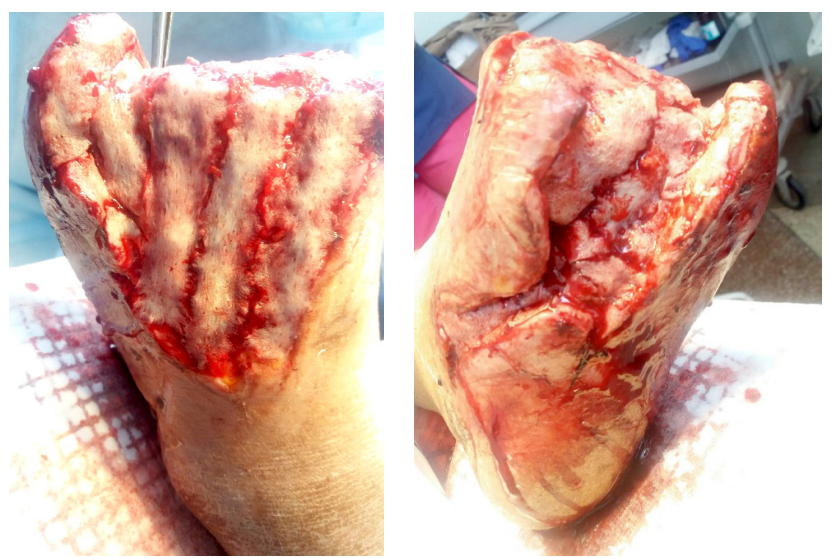

Рис. 12. Автодермопластика за методом Тірша. Після електромеханічного дебридменту повна адгезія трансплантанту.

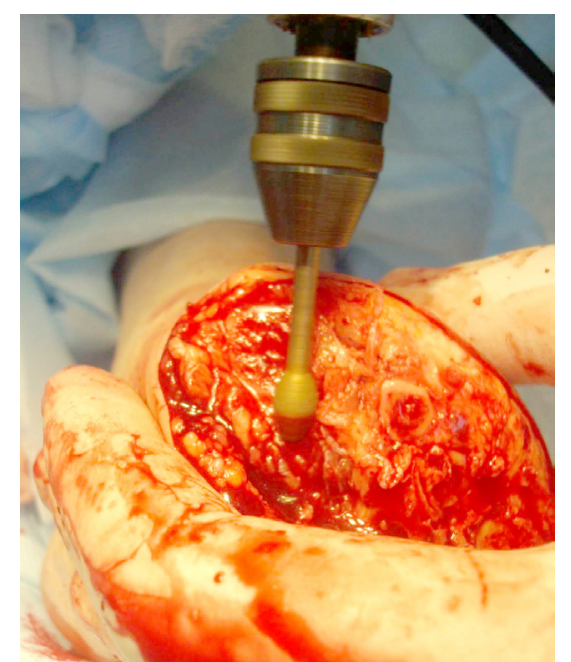

Рис. 14. Обробка країв плесневих кісток та електромеханічний дебридмент м’яких тканин. 
нали ранню ксенопластику (за умов відмови пацієнта від автодермопластики) в 7 та автодермопластику у 18 хворих, що дала можливість повністю закрити дефект рани (рис. 15-18).

У післяопераційному періоді, застосовуючи вказані методики електромеханічного відсікання та обробки кісток, лише у 2-х випадках при нейропатичній формі було виявлено розвиток пресорних виразок у проекції культі 1-ї плюсневої кістки

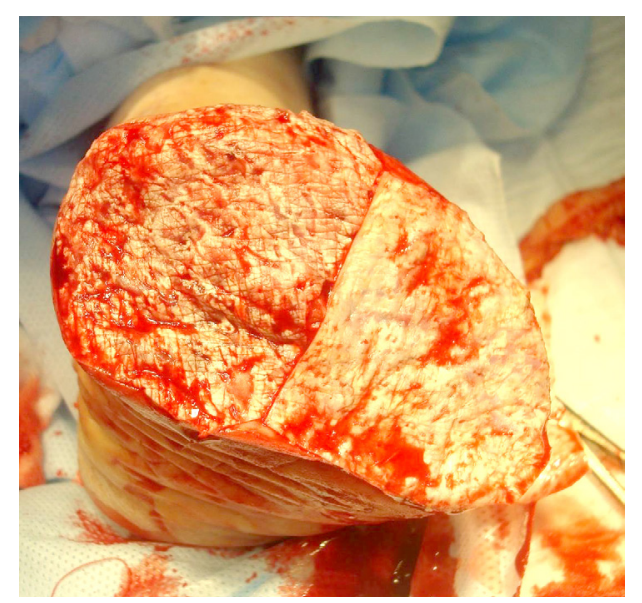

Рис. 15. Накладання ксенотрансплантанту.

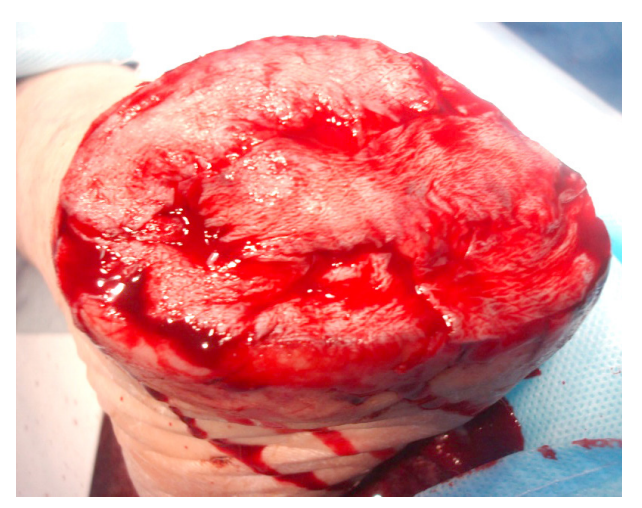

Рис. 16. Автодермопластика.

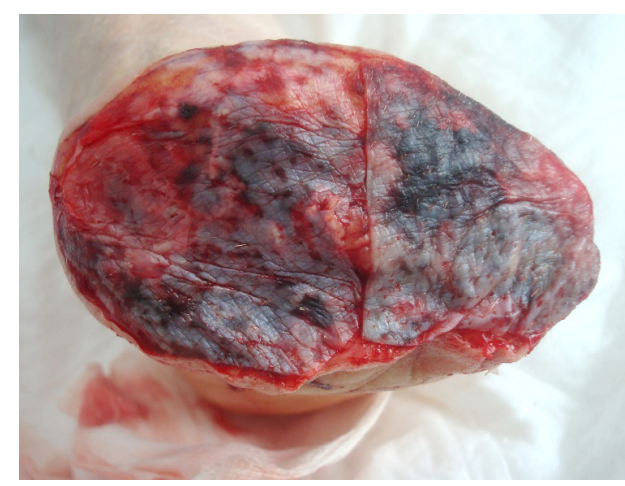

Рис. 17. Вигляд кукси після ксенопластики через 7 діб після операції. Формування грануляційної тканини.

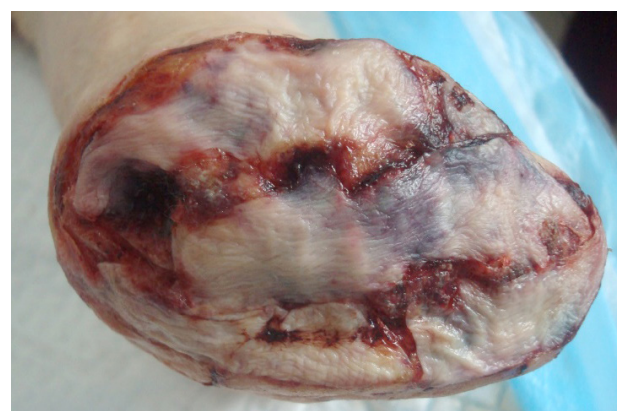

Рис. 18. Вигляд кукси після автодермопластики через 7 діб після операції. Повне приживлення автошкіри, констрикція рани, відсутність набряку кукси та гомілки.

по підошовній поверхні, які після звернення пацієнта були успішно кореговані консервативними методами лікування. При невроішемічній чи ішемічній формах всім 7 пацієнтам, яким виконана ксенопластика після їх виписування із стаціонару, була потреба повторної ксенопластики по другому разу та 2 - по третьому, однак впродовж в середньому $(42 \pm 2,3)$ доби культя повністю загоїлася і лише в одного пацієнта після ранньої автодермопластики культя на 12 добу потребувала повторної - для незначного дефекту кукси та повністю загоїлася до 26 доби в амбулаторних умовах.

Висновки. Лікування будь-яких ускладнень при СДС потребує комплексного диференційованого патогенетичного підходу. Застосування електромеханічного вібраційного та обертового методик обробки культі дає можливість значно зменшити час загоєння ранових поверхонь, уникнути травматизації м’яких тканин після подальшого навантаження на культю при ходьбі, зменшити больові відчуття та утворення післяопераційних ускладнень, що є важливим для якості життя такої категорії пацієнтів. Виконання гільйотинної ампутації при невроішемічній чи ішемічній формах СДС $з$ ранньою ксено- чи автодермопластикою при неможливості проведення реконструктивних судинних операцій є пріоритетною для даної категорії пацієнтів. Електромеханічний дебридмент м’яких тканин утворює на поверхні рани плівку із зруйнованих поверхневих клітин м’язів, крові, фібрину, що сприяє швидкій та міцній адгезії як ксенотрасплантанта, так і автодермотрансплантанта.

Перспективи подальших досліджень. Дослідження якісного складу клітин на поверхні рани, що сприяє добрій адгезії трансплантантів та пришвидшення її регенерації є предметом подальших наших досліджень. 


\section{З ДОСВІДУ РОБОТИ}

\section{СПИСОК ЛІТЕРАТУРИ}

1. Бойко В. В. Деякі концептуальні питання синдрому діабетичної стопи / В. В. Бойко, В. К. Логачов, С. О. Береснєв // Клінічна ендокринологія та ендокринна хірургія. - 2008. № 3 (24). - С. 46-47.

2. Синдром діабетичної стопи. Діабетична периферійна невропатія / С. М. Василюк, А. Г. Шевчук, В. М. Федорченко [та ін.] // Art of Medicine. - 2019. - № 1 (9). - С. 21-26.

3. Результати комплексного диференційованого лікування хворих із синдромом діабетичної стопи / П. О. Герасимчук, I. М. Дейкало, С. Й. Запорожан [та ін.] // Вісник наукових досліджень. - 2017. - № 2. - С. 77-38.

4. Синдром діабетичної стопи: остеомієлітичні ураження / І. Д. Герич, Р. В. Яремкевич, Д. Л. Романчак, О. М. Козій // Хірургія України. - 2009. - № 3. - С. 27-33.

5. Дзюбановський І. Я. Комплексне хірургічне лікування хворих із гнійно-некротичними ускладненнями на грунті синдрому діабетичної стопи / I. Я. Дзюбановський, Р. Я. Антощук // Вісник науковиї досліджень. - 2016. - № 4. - C. $52-54$.

6. Заремба В. С. Алгоритми діагностики, прогностичної оцінки та лікування синдрому діабетичної стопи / В. С. Заремба // Хірургія України. - 2009. - № 2. - С. 37-43.

7. Свиридов Н. В. Комплексное дифференцированное хи- рургическое лечение гнойно-некротических поражений стопы у больных сахарным диабетом : монография / Н. В. Свиридов, В. Ю. Михайличенко, Н. Н. Бондаренко. - Донецк : Юго-Восток, 2014. - 280 с.

8. Пат. на корисну модель 109065 Україна, МПК (2015) Спосіб ампутації фаланги пальця у хворих на синдром стопи діабетика / Футуйма Ю. М., Чонка І. І., Павлишин А. В. ; заявник та патентовласник Терноп. держ. мед. ун-т імені І. Я. Горбачевського. - 2016, Бюл. № 15.

9. Шкварковський І. В. Застосування вакуум-кавітаційних методів санації в лікуванні синдрому діабетичної стопи / I. В. Шкварковський, Т. В. Антонюк, О. І. Філіпець // Шпитальна хірургія. - 2014. - № 1. - С 45-48.

10. Armstrong D. G. Efficacy of fifth metatarsal head resection for treatment of chronic diabetic foot ulceration / D. G. Armstrong, M. A. Rosales, A. Gashi // J. Am. Podiatr. Med. Assoc. - 2014. Vol. 95 (4). - P. 353-356.

11. Boulton A. J. International collaboration on the diabetic foot: a 15- year progress report / A. J. Boulton // Diabet. Metab. Res. Rev. - 2004. - Vol. 20 (Suppl. 1). - P. 2-3.

12. Chao C. Y. The association between skin blood flow and edema on epidermal thickness in the diabetic foot / C. Y. Chao // Diabetes Technol. Ther. - 2012. - Vol. 14 (7). - P. 602-609.

\section{REFERENCES}

1. Boyko, V.V., Lohachov, V.K., \& Beresnyev, S.O. (2008). Deiaki kontseptualni pytannia syndromu diabetychnoi stopy [Some conceptual questions of diabetic footsyndrome]. Klinichna endokrynolohiia ta endokrynna khirurhiia - Clinical Endocrinology and Endocrine Surgery, 3 (24), 46-47. DOI: https://doi. org/10.24026/1818-1384.3(24).2008.118495 [in Ukrainian].

2. Vasyliuk, S.M., Shevchuk, A.H., Fedorchenko, V.M., Osadets, V.S., Krymets, S.A., \& Vasyliuk, A.S. (2019). Syndrom diabetychnoi stopy. Diabetychna peryferiina nevropatiia [Diabetic foot syndrome. Diabetic peripheral neuropathy]. Art of Medicine, 1 (9), 21-26. DOI: 10.21802/artm.2019.1.9.21 [in Ukrainian].

3. Herasymchuk, P.O., Deikalo, I.M., Zaporozhan, S.Y., Fira, D.B., Hospodarskyi, A.Ya., \& Sydorenko V.M. (2017). Rezultaty kompleksnoho dyferentsiiovanoho likuvannia khvoryykh iz syndromom diabetychnoi stopy [Results of complex differential treatment of patients with diabeticfootsyndrome]. Visnyk naukovykh doslidzhen - Bulletin of Scientific Research, 2, 77-38. DOI: https://doi.org/10.11603/2415-8798.2017.2.7838 [in Ukrainian]. 4. Gerych, I.D., Yaremkevych, R.V., Romanchak, D.L., \& Koziy, O.M. (2009). Syndrom diabetychnoi stopy: osteomiielitychni urazhennia [Diabetic foot syndrome: osteomyelitis damage]. Khirurhiia Ukrainy - Surgery of Ukraine, 3, 27-33 [in Ukrainian]. 5. Dzyubanovskyi, I.Ya., \& Antoshchuk, R.Ya. (2016). Kompleksne khirurhichne likuvannia khvorykh iz hniino-nekrotychnymy uskladnenniamy na hrunti syndromu diabetychnoi stopy [Complex surgical treatment of patients with purulent-necrotic complications due to diabetic foot syndrome]. Visnyk naukovykh doslidzhen - Bulletin of Scientific Research, 4, 52-54. DOI: https:// doi.org/10.11603/2415-8798.2016.4.7146 [in Ukrainian].

6. Zaremba, V.S. (2009). Alhorytmy diahnostyky, prohnostychnoi otsinky ta likuvannia syndromu diabetychnoi stopy [Algorithms for diagnosis, prognostic assessment and treatment of dia-

betic foot syndrome]. Khirurhiia Ukrainy - Surgery of Ukraine, 2, 37-43 [in Ukrainian].

7. Sviridov, N.V., Mikhaylichenko, V.Yu., \& Bondarenko, N.N. (2014). Kompleksnoye differentsirovannoye khirurgicheskoye lecheniye gnoyno-nekroticheskikh porazheniy stopy u bolnykh sakharnym diabetom: monografiya [Complex differentiated surgical treatment of purulent-necrotic lesions of the foot in patients with diabetes mellitus: monograph]. Donetsk: Yugo-Vostok [in Russian].

8. Futuima, Yu.M., Chonka, I.I., \& Pavlyshyn, A.V. (2016). Pat. Ukrainy 109065 na korysnu model MPK (2015) Sposib amputatsii falanhy paltsia u khvorykh na syndrom stopy diabetyka [Pat. Ukraine 109065 on a utility model IPC (2015) Method of amputation of the phalanx of the finger in patients with diabetic foot syndrome]; zaiavnyk ta patentovlasnyk Ternop. derzh. med. un-t imeni I. Ya. Horbachevskoho. Byul. No. 15 [in Ukrainian].

9. Shkvarkovskyi, I.V., Antoniuk, T.V., \& Filipets, O.I. (2014). Zastosuvannia vakuum-kavitatsiinykh metodiv sanatsii v likuvanni syndromu diabetychnoi stopy [The use of vacuum-cavitation methods of rehabilitation in the treatment of diabetic foot syndrome]. Shpytalna khirurhiia - Hospital Surgery, 1, 45-48. DOI: https://doi. org/10.11603/1681-2778.2014.1.4363 [in Ukrainian].

10. Armstrong, D.G., Rosales, M.A., \& Gashi, A. (2014). Efficacy of fifth metatarsal head resection for treatment of chronic diabetic foot ulceration. J. Am. Podiatr. Med. Assoc, 95 (4), 353-356. DOI: $10.7547 / 0950353$.

11. Boulton, A.J. (2004). International collaboration on the diabetic foot: a 15- year progress report. Diabet. Metab. Res. Rev., 20 (Suppl. 1), 2-3.

12. Chao, C.Y. (2012). The association between skin blood flow and edema on epidermal thickness in the diabetic foot. Diabetes Technol. Ther., 14 (7), 602-609. DOI: 10.1089/dia.2011.0301.

Отримано 04.03.2021 
YU. M. FUTUIMA, A. D. BEDENYUK, I. YA. KULBABA

I. Horbachevsky Ternopil National Medical University

\title{
PRIORITY IN CHOOSING THE METHOD OF SURGICAL STUMP CORRECTION AFTER AMPUTATION OF THE DISTAL FOOT IN PATIENTS WITH DIFFERENT FORMS OF DIABETIC FOOT SYNDROME
}

The aim of the work: to improve the results of surgical treatment of patients with various forms of diabetic foot syndrome by choosing adequate closure of the stump defect after transmetatarsal amputation.

Materials and Methods. The analysis of the results of treatment of 72 patients with complicated type II diabetes mellitus was performed. The neuropathic form predominated and amounted to $65.3 \%$, neuro-ischemic $-29.2 \%$ and ischemic - $5.5 \%$ of all operated patients. All had stage III and IV distal foot lesions according to the Meggit-Wagner classification. All patients underwent transmetatarsal amputation. To prevent complications in the postoperative period, amputations of the distal part of the foot were performed by electromechanical vibration technique with closure of the stump in neuropathic form with a free lower flap and in neuro-ischemic or ischemic forms of diabetic foot syndrome using early xeno- or autodermoplasty after the heliotic method of amputation.

Results and Discussion. This approach allowed us to close the defect of the distal stump in those groups of patients with neuro-ischemic and ischemic forms of diabetic foot syndrome, where vascular reconstructive surgery was not possible on clinical and diagnostic grounds.

Key words: diabetic foot syndrome; transmetatarsal amputation; electromechanical debridement; xenoplasty; autodermoplasty.

\section{ПРИОРИТЕТНОСТЬ В ВЫБОРЕ МЕТОДА ХИРУРГИЧЕСКОЙ КОРРЕКЦИИ КУЛЬТИ ПОС.ЛЕ АМПУТАЦИИ ДИСТАЛЬНОГО ОТДЕЛА СТОПЫ У БОЛЬНЫХ С РАЗЛИЧНЫМИ ФОРМАМИ СИНДРОМА ДИАБЕТИЧЕСКОЙ СТОПЫ}

\begin{abstract}
Цель работы: улучшить результаты хирургического лечения больных с различными формами синдрома диабетической стопы путем выбора адекватного закрытия дефекта культи после трансметатарзальной ампутации.

Материалы и методы. Проведен анализ результатов лечения 72 больных с осложненным сахарным диабетом 2 типа. Невропатическая форма преобладала и составляла 65,3 \%, невро-ишемическая - 29,2 \% и ишемическая - 5,5 \% из всех оперированных пациентов. У всех были поражения дистального отдела стопы 3 и 4 стадий по классификации Meggit-Wagner. Bсем пациентам выполнено трансметатарзальную ампутацию. Для предупреждения осложнений в послеоперационном периоде выполнение ампутаций дистального отдела стопы осуществляли электромеханически-вибрационной методикой с последующим закрытием культи при нейропатической форме с помощью свободного нижнего лоскута, а при нейро-ишемической или ишемической формах синдрома диабетической стоп с применением ранней ксено- или аутодермопластики после гельйотинного метода ампутации.

Результаты исследований и их обсуждение. Данный подход позволил нам закрыть дефект дистального отдела культи в тех группах пациентов с нейро-ишемической и ишемической формами синдрома диабетической стопы, где выполнение сосудистых реконструктивных операций не представлялось возможным по клинико-диагностическим признакам.
\end{abstract}

Ключевые слова: синдром диабетической стопы; трансметатарзальная ампутация; электромеханический дебридмент; ксенопластика; аутодермопластика. 